\title{
Youth Cinema: Young Taiwanese Lesbian on Screen
}

\author{
Wang Chang Song \\ Universiti Sains Malaysia, Malaysia \\ Chen Yiming \\ Jinan University, China \\ Rohani Hashim \\ Universiti Sains Malaysia, Malaysia
}

Accepted: August 28, 2012 Published: September 29, 2012

Doi:10.5296/jsr.v3i2.2482 URL: http://dx.doi.org/10.5296/jsr.v3i2.2482

\begin{abstract}
This study offers an analysis of lesbian affairs depicted in Hsiao-tse Cheng's Miao Miao (2008). Reading this production alongside the representations of lesbian, the authors argue that homosexual affair represented in this film involves nothing more than interpersonal issues with lively audience interaction as this film skimms the surface of its subject matter, especially regarding 'genital stage' in personality development, and also, the survey conducted in Taiwan shows that there is a considerable number of young Taiwanese cinema-goers are more concern on psychosexual issues, compare with other themes. This film is an example of Taiwan-Hong Kong co-production and a feature debut by a Taiwanese young film director. Colours, natures, gestures and other means of expression therefore have exhibited a unique look for Taiwanese youth cinema.
\end{abstract}

Keywords: LGBTQ, youth cinema, representations of homosexuality, Taiwanese films, Taiwan

\section{Introduction}

So much filmmaking and so many discussions in Taiwanese culture have focused on queer youth that it seems natural that a study of queer representations of dissenting youth should include a chapter from a necessary perspective. Robert Chen stated in my interview, almost each year one or two domestic LGBTQ (lesbian, gay, bisexual, trans \& queer) films in the decade beginning in 2001 could be seen in cinema and sometime even more than two. Two lesbian drama films produced in 2007: Ci Qing/Spider Lilies (Zero Chow, 2007) and Wo Kan Jian ShoulI Saw A Beast (Liu Yi-Hong, 2007). There are many well-known periods and queer genre that could be explored as possible comparisons, including Taiwanese gay films of the 1990s such as Xi Yan/The Wedding Banquet (Ang Lee, 1993) and Qing Shao Nian Ne ZhalRebels of the Neon God (Tsai Ming-liang, 1993), and queer youth films of the late 2000s. In this study, the film Miao Miao (Hsiao-tse Cheng, 2008) is highlighted to indicate the 
representations of homosexuality in Taiwanese cinema.

After some preliminary research into all of them, I concluded that Miao Miao, Winds of September and Summer's Tail are similar in the themes of adolescences, secondary school students and teenagers who dream, struggle and overcome their own difficulties without their parents around as if they do not need to be controlled by any laws or rules that govern them. Youths in the Taiwanese youth films (i.e. the brotherhood-theme films such as Winds of September) want to be well liked and popular with others, and they want to be an individual doing their own thing together as relationship among peers is very important for their male bonding. They want to be accepted and often go to great lengths to fit in. In terms of sexual representations, these groups of films (1) portray sexual interests and engaging in sexual activity in their relationship with members of either the opposite or same sex; (2) tend to suspend adult perspectives and value judgements for exploring their own experiences and interests of adolescences; and (3) embrace gay/lesbian diversity in new ways. This section of the chapter, I have decided to explore only a single LGBTQ film, as one example seems sufficient to indicate both the general similarities and the specific differences among other Taiwanese youth films.

\section{The Synopsis: Miao Miao (Directed by Hsiao-Tse Cheng, 2008)}

Miao Miao (2008) depicts two girls' innocent discoveries of first love. High school student Miao Miao (played by Ke Jia-Yan) is Chinese but is raised in Japan, and has transferred to Taipei as an exchange student. She intends to find the bakery shop where her grandma's first love was. At her Taiwan high school, her quiet demeanor and grace make her attractive once she is enrolled, but the sassy Chen Ai Yuan/Xiao Ai (played by Sandrine Pinna) cracks her shell. They become fast friends, palling around after school, learning more about pastry. The girls' relationship changes in the process of preparing a baking contest. Miao Miao finds first love when she falls for sullen CD shop owner Chen Fei (played by Fan Chih-Wei) who's shutting out the world with a pair of headphones. Xiao Ai helps Miao Miao to quietly wriggle her way into Chen Fei's life, but finds herself falling for Miao Miao, leading to an extra layer of tension in their tumultuous young lives. Chen Fei searches high and low for a rare CD demo that actually has something to do with his sad past. The singer of the CD demo is Chen's band's male singer Xiao Bei, who has a relationship with Chen. Miao Miao leaves the memory of her first love at Chen's CD shop, which was exactly the cake shop of her grandma's memory of first love, and heads back to Japan. Xiao Ai only pours out her love after Miao Miao's flight takes off.

\section{Film Analysis: Miao Miao (2008)}

This film moves at a slow pace and most of the characters are given more distressed exposition than there needs to be. The film was criticized domestically for its lapses in measuring the themes. Cheng Bin-Hong (2010) points out that the scriptwriter, film producer and film director have no idea what they want this film to be, and he leaves quite a few question marks in the comments, including the problems of elaboration of youth confusion, 
sexual orientation, and youth romance. Cheng also mentioned the 'schizoid narrative' (Jing Shen Fen Lie Xu Shi Zi Tai) even messes the love story with a gay romance. In this way, however, the film director just simplifies the issue of human sexuality, since the main characters are mostly depicted as homosexuals. In the earlier discussion about the narrative pace of the film Winds of September, 'slowness' has been quoted as remarking to the cinema-goers that they are more motivated to read slower, and coincidently, or traditionally, the story of the film Miao Miao (2008) moves at a slow rate. It might not disrupt the structure of Taiwanese narrative film. The impact of the slow pace will be illustrated by the following.

Firstly, the lesbian affair and gay affair represented in Miao Miao (2008) attempt not to construct some subtle comparisons in terms of male and female characters' fates, but to involve nothing more than interpersonal issues with lively audience interaction as this film skims the surface of its subject matter, especially regarding 'genital stage' in personality development, and also, because my survey conducted in Taiwan shows that there are a considerable number of young Taiwanese cinema-goers concerned with psychosexual issues depicted in domestic youth films, rather than other themes.

According to Sigmund Freud (1998), personality is mostly established by the age of five. Early experiences of the individual play a large role in personality development and continue to influence behavior later in life. Our personality develops through a series of childhood stages during which the pleasure-seeking energies of the id turn to focus on certain 'erogenous zones' (Rathus, Spencer A, and Jeffrey S. Nevid, 1998). During each stage, an unsuccessful completion indicates the individual's resolving the developmental conflict of the immediate stage. In the latency stage, 'sexual urges remain repressed and children are interested in and play mostly with same-sex peers, and the pleasure source, or sexual urges' (Eagle and Lillian, 1994), in this stage 'sublimates into sports and hobbies' (Eagle and Lillian, 1994). The final stage of psychosexual development - genital stage - begins at the start of puberty when sexual urges are once again awakened and through the lessons learned during the previous stages, adolescents direct their sexual urges onto opposite sex peers, with the primary focus on pleasures is the genitals. Freud (1989) believed physical sexual changes reawaken repressed needs, and also, direct sexual feelings towards others lead to sexual gratification.

The female characters depicted in the film Miao Miao (2008) are about 17 years old, the years of young adolescent. And the stories of both of the female adolescents touch a bit about their childhood, especially Xiao Ai, who does not speak much to her father since she saw him and a woman in his bedroom when she was in sixth grade (around 12 years old). Some existing researches ${ }^{1}$ show that 'Sixth grade' in Taiwanese girls is typically the start of puberty. According to Freud (1989), genital stage begins during puberty but last throughout the rest of a person's life; if the other stages have been completed successfully, the individual should now be well-balanced, warm and caring. The goal of the genital stage is to establish a balance between the various life areas. This film slightly depicts that Xiao Ai refuses to 'speak' to her father though her father prepares breakfast daily for her no matter how she tries to avoid him. It might be concluded that Xiao Ai is not 'well-balanced' after the genital stage. 
So, where Xiao Ai gets her 'warm' feeling? In this film, an interesting representation of lesbianism is 'a warm hand', and in the film it is quoted as 'sunshine hand'. Two good examples: firstly, Xiao Ai's algomenorrhea scene - in the car of the Taipei MRT (Taipei Mass Rapid Transit) train, Xiao Ai sitting huddled up because of her algomenorrhea and holding Miao Miao's 'warm hand' to cover her abdomen at her convenience; secondly, when saying farewell to Miao Miao at the airport, Xiao Ai receives a cake present from Miao Miao with a two-hands-image cake topper which definitely signifies two hands of the two females. Taking such a relationship as given, it does not explore the dimensions of power involved in a particular lesbian relationship. However, 'warm hand' is a clear tool to discover the emotional affair between the two females. It is worthy to note, that the homosexual identity development is much more clearly embraced by the depiction of the character Xiao Ai. Much of the work on identity development in relation to sexuality (e.g., Ritch Savin-Williams, 2005) and gender identity (e.g., Grossman et al., 2006) suggest that LGBT young people can be recognized from an early age by characteristics such as childhood feelings of 'different' and gender atypical behavior, appearance or interests (Clark, Sonjia, Elizabeth and Damien, 2010). The extract from the film here refers to a number of sequences that specifically imply the homosexual identity development. The example sequences and the most frequently cited model - Viviene Cass's (1979) six-stage model of 'homosexual identity formation' (Clark, Sonjia, Elizabeth and Damien, 2010) - are captured in the table below:

Table 4: Model of homosexual identity formation \& example sequences in film

\begin{tabular}{|c|c|c|}
\hline \multicolumn{2}{|c|}{$\begin{array}{l}\text { Vivienne Cass's (1979) model of } \\
\text { homosexual identity development }\end{array}$} & $\begin{array}{l}\text { Example sequences } \\
\text { in the film Miao Miao (2008) }\end{array}$ \\
\hline Stage 1 & $\begin{array}{l}\text { Identity confusion }- \text { A } \\
\text { conscious awareness that } \\
\text { homosexuality is relevant to } \\
\text { oneself and/or one's behavior. }\end{array}$ & Not visualized \\
\hline Stage 2 & $\begin{array}{l}\text { Identity comparison } \\
\text { incongruency } \\
\text { perception of self as } \\
\text { homosexual and others' } \\
\text { perceptions of one's } \\
\text { homosexual results in feeling of } \\
\text { alienation from peers and a } \\
\text { sense of self as not belonging } \\
\text { or being different. }\end{array}$ & Not obvious \\
\hline Stage 3 & $\begin{array}{l}\text { Identity tolerance }- \text { A greater } \\
\text { level of commitment to } \\
\text { self-image as homosexual and } \\
\text { acknowledgment of social, } \\
\text { emotional and sexual needs }\end{array}$ & $\begin{array}{l}(53: 47-54: 35) \\
\text { Xiao Ai request an 'adult drink' from her } \\
\text { uncle but refused by him as he considers } \\
\text { Xiao Ai is still a 'kid'; } \\
\text { The uncle, however, gives her wine and }\end{array}$ \\
\hline
\end{tabular}




\begin{tabular}{|c|c|c|}
\hline & $\begin{array}{l}\text { results in heightened alienation } \\
\text { from the heterosexual world } \\
\text { and actively seeking out other } \\
\text { homosexuals and the } \\
\text { homosexual subculture. }\end{array}$ & $\begin{array}{l}\text { says 'my little cousin's all grown up' after } \\
\text { Xiao Ai tells him a secret which she } \\
\text { highlights not to tell anyone else. } \\
\text { (The secret is not visualized on screen) }\end{array}$ \\
\hline Stage 4 & $\begin{array}{l}\text { Identity acceptance }- \text { Contact } \\
\text { with other homosexuals } \\
\text { becomes more frequent and } \\
\text { regular. A preference for } \\
\text { homosexual social contexts and } \\
\text { the development of friendships } \\
\text { within them is established. }\end{array}$ & $\begin{array}{l}\text { Contact with other lesbian is not visible } \\
\text { on screen. }\end{array}$ \\
\hline Stage 5 & $\begin{array}{l}\text { Identity pride }- \text { commitment } \\
\text { to the gay group is strong, } \\
\text { generating a sense of group } \\
\text { identity. Preference for } \\
\text { homosexual identity rather than } \\
\text { heterosexual identity. }\end{array}$ & $\begin{array}{l}\text { Commitment to the homosexual group is } \\
\text { invisible for either female characters or } \\
\text { the male characters. } \\
(1: 17: 42 \text { - } 1: 19: 41) \\
\text { Xiao Ai keeps running outside of airport } \\
\text { pavement; } \\
\text { She stops running and she speaks to the } \\
\text { sky: } \\
\text { "Miao Miao, I'll miss your homemade } \\
\text { bread and your warm hands. Miao Miao, } \\
\text { I like you so much. I really like you. But } \\
\text { you don't even know." }\end{array}$ \\
\hline Stage 6 & $\begin{array}{l}\text { Identity synthesis } \\
\text { homosexual identity is } \\
\text { integrated into other aspects of } \\
\text { self. Rather than the identity, it } \\
\text { is seen merely as one aspect. }\end{array}$ & Not obvious \\
\hline
\end{tabular}

The comparison between the example sequences in the film and the model of homosexual identity formation shows that the process of the homosexual identity development is not perfectly visible in this film, but the awareness of characters' homosexual feelings exists. Cheng Bin-Hong (2010) argues that the contrast between gay love and lesbian love supposes to involve some touching plots but what the cinemagoers can see is only the tedious conversations. And, the mise-en-scene and camera movement were criticized as well. Despite the slings and arrows of film comments, this film successfully reveals interpersonal issues with lively audience interaction. This film basically depicts the normal process of psychosexual development. On the other hand, it basically embraces the basic elements of homosexual identity development. 'By the mid-1980s there were a number of models describing the process of coming to identify as lesbian or gay, and there are four main elements common to all of the models: (1) an awareness of homosexual feelings; (2) exploration of homosexuality; 
(3) taking on board a lesbian/gay self-identity; and (4) integrating one's lesbian/gay identity into one's broader sense of self' (Clark, Sonjia, Elizabeth and Damien, 2010). Therefore, the common elements are perfectly shown through the main characters.

The authors argue that this LGBTQ film satisfies the audiences' need on this subject, because the Taiwanese people show more interests on psychosexual issues depicted in Taiwanese youth films rather than other themes in the random select survey ${ }^{2}$ (margin of error: 0.071) among Taipei residents with ages from eighteen to forty years old. The objective of the online survey was to gather data about the Taiwanese public preference for the issue of youth cinema. The result shows that $69.44 \%$ survey participants would be more interested on the themes/plots/sequences in terms of psychosexuality, $23.61 \%$ participants express their interests in other film issues and $6.94 \%$ participants show the indeterminacy of the favourite film issue. For example, a gay participant (age 38) said that these kinds of issues are more visible in domestic youth cinema rather than other genre films; a straight male participant (at age 27) said that he had more interest in discovering the real reasons behind these kinds of plots and themes, such as the environmental or external causes. On the other hand, interestingly, a few survey participants would like to see the issues about environmental-friendliness, science and subculture in the domestic youth film productions.

Furthermore, as mentioned in the introduction, it is common that Taiwanese youth cinema emphasizes the sentimental approach, but this film attenuates its norm characteristics mainly due to this film being produced by Hong Kong film master Wong Kar-wai's Jet Tone Production Company for the first time in the Taiwanese film industry. In the crew list, Wong Kar-wai's ordinary members of his 'theatrical troupe' can be seen. For example, Kwan Pun Leung, the photographic director of Miao Miao, who is a co-director of photography for the film 2046 (Wong Kar-wai, 2004), co-director of photography for the film Hua Yang Nian Hua/In The Mood For Love (Wong Kar-wai, 2001), director of photography for Wong's short films Chacun son cinéma/To Each His Cinema (2007), and director of photography and editor for the short film Blueberry Days (2009); William Chang Suk Ping, the film editor of Miao Miao, who has participated in all of Wong Kar-Wai's films; and also, Stanley Kwan, one of the producers, who is a well-known Hong Kong film director and producer.

Backed by the solid production team that originally comes from Hong Kong, this film is presented with an aura of prestige from the start - a whirl of bright, colorful jump cuts painted in catalog gloss where the cinematographer turns out to have an eye for imagery and composition at the same time. In the frame of a rostrum in the classroom, two interesting signs: 'Xiong' (bear) and 'Baby in Car' - which in fact are popular personalized car signs - caught the authors' attention. From a social semiotic perspective, rather than being fixed into unchanging codes, signs are considered to be resources which people use and adapt. A linguistic sign is not a link between a thing and a name, but between a concept and a sound pattern. The sound pattern is not actually a sound; for a sound is something physical. A sound pattern is the hearer's psychological impression of a sound, as given to him/her by the evidence of his/her senses. The personalized car sign "Xiong", just a single Chinese character, signifies that 'I am dangerous and keep a distance from me as I am new'. Obviously, the rostrum is physically not 


\section{Macrothink

an auto, and the drawing 'car sign' on it indicates imagery that is basically the 'distance' between students and a teacher, and the even sound pattern of a bear's utterance make sense here as well. After a satirization against Xiao $A i$, the teacher punishes her by having her stand in a corner of the classroom. They are colorful and interesting sequence combinations, but the strong conflicts between young adolescents and adults are attenuated.

\section{Funding}

This research was financially supported by the School of Communication, Universiti Sains Malaysia.

\section{Note}

1. The authors reviewed some of the Taiwanese scholars' works in terms of Taiwanese adolescents and puberty, for example, the published paper entitled 'the first sunlight beyond the clouds: researching the motherhood experiences for the newly immigrant females with teenaged children' written by Shu-Ling Huang in 1996.

2. This survey is conducted by Wang Chang Song during May to June 2012 in the region of Taipei, Taiwan.

\section{References}

Bin-Hong, Cheng. (2010). The Love and Death of Taiwan Cinema. Taipei: Bookman Books Publishing House.

Clarke, Victoria, Sonjia J. Ellis, Elizabeth Peel and Damien W. Riggs. (2010). Lesbian, Gay, Bisexual, Trans and Queer Psychology. UK: Cambridge University Press.

Eagle, Carol J., and Lillian Schwartz. (1994). Psychological portraits of adolescents: an integrated development approach to psychological test data, Lexington Books.

Rathus, Spencer A, and Jeffrey S. Nevid. (1989). Psychology and the challenges of life : adjustment and growth (fourth edition). US: Holt, Rinehart, and Winston

\section{Bios}

Mr. Wang Chang Song received a B.A. with honor in advertising from the Soochow University, China, and Master of Communication from the Universiti Sains Malaysia. He is currently doing his PhD degree on film and broadcasting in USM. He was awarded with USM fellowship in year 2011; and is recipient of Vice-Chancellor's Award for year 2012. Research fields: film and broadcasting, film studies, Chinese cinema, media studies, and new media.

Mr. Yiming Chen is a lecturer at the School of Journalism and Communication, Jinan University, China. Research fields: film and visual culture, media and communication, radio 
and TV.

Dr. Rohani Hashim is an associate professor at the Film \& Broadcasting Section, School of Communication, Universiti Sains Malaysia. She obtained her bachelor degree in mass communication from USM, Master of Fine Art in film from Ohio University, USA and PhD from Monash University, Autralia. Research fields: film and broadcasting, audio/radio studies, film studies, television studies, visual communication, new media, media studies, and environmental journalism. 